\title{
Expression patterns of leukaemia inhibitory factor receptor (LIFR) and the gp130 receptor component in rabbit uterus during early pregnancy
}

\author{
Z-M. Yang ${ }^{1}$, S-P. Le ${ }^{1}$, D-B. Chen ${ }^{1}$, K. Yasukawa ${ }^{2}$ and \\ M. J. K. Harper ${ }^{1 *}$ \\ ${ }^{I}$ Department of Obstetrics and Gynecology, Baylor College of Medicine, Houston, TX 77030, USA; and \\ ${ }^{2} \mathrm{TOSOH}$ Corporation, Kanagawa-ken, Japan
}

\begin{abstract}
The presence of leukaemia inhibitory factor (LIF) binding and expression of the gp130 component of the LIF receptor were studied in the rabbit uterus during early pregnancy. LIF binding to myometrium was moderate in oestrous and non-oestrous animals and on day 1 of pregnancy, declined on days 2 and 3, and increased to a peak value on days 5 and 6 of pregnancy. Binding to stromal cells was not observed. Binding of LIF to luminal and glandular epithelium was low in unmated animals and on days 1 and 2 of pregnancy. Binding to luminal epithelium increased from day 3 , and to glandular epithelium from day 5 of pregnancy. Highest binding was seen on days 5 and 6 , with a slight decline observed on day 7, and with little difference between the mesometrial and antimesometrial regions of the implantation site. In all cases, binding of LIF was similar in the uteri of day 6 pseudopregnant and pregnant animals. At all stages, gp130 was absent from stroma and almost absent from myometrium and glandular epithelium. It was expressed in luminal epithelium, reaching maximal expression on day 6 of pregnancy and pseudopregnancy, but diminished on day 7 of pregnancy, particularly in the antimesometrial area of the implantation site. The coexpression of LIF binding and gp130 may indicate the presence of high-affinity LIF receptor, which matches the pattern of LIF protein expression and, as in mice, suggests its importance for implantation.
\end{abstract}

\section{Introduction}

Leukaemia inhibitory factor (LIF) is a glycoprotein with pleiotropic activity on a wide variety of cell types in vitro, including embryonic stem cells (Smith et al., 1988), primordial germ cells (Matsui et al., 1992), myeloid cell lines (Hilton et al., 1988; Moreau et al., 1988), adipocytes (Mori et al., 1989), hepatocytes (Baumann and Wong, 1989) and peripheral neurones (Yamamori et al., 1989).

LIF is expressed in cultured mouse blastocysts and particularly in the uterus (Murray et al., 1990; Bhatt et al., 1991). Abundant mRNA expression is found in the mouse uterus on day 4 of pregnancy, which is just before implantation of blastocysts (Bhatt ef al., 1991). A study with homozygous $\mathrm{LIF}^{-} / \mathrm{LIF}^{-}$mice has shown that maternal LIF expression is essential for the implantation of mouse blastocysts (Stewart et al., 1992). Our previous results showed that LIF protein was highly expressed in the rabbit uterus before implantation (days 5 and 6) and so may also be important for the implantation of rabbit blastocysts (Yang et al., 1994).

The action of LIF is mediated by binding to cell surface receptors. Equilibrium analysis of the binding of radioiodinated LIF has led to the classification of two receptor types, low affinity and high affinity (Yamamoto-Yamaguchi et al., 1986;

\footnotetext{
${ }^{*}$ Reprint requests
}

Received 31 May 1994.
Hilton et al., 1988, 1991). The cloned LIF receptor (LIFR) binds only LIF with low affinity, but subsequent binding of gp130, a signal-transducing receptor component of LIF, interleukin 6 (IL-6) and ciliary neurotrophic factor receptors transforms the low-affinity LIFR $\beta$ into a high-affinity form, and activates signal transduction; gp130, by itself, does not bind LiF (Gearing et al., 1991, 1992; Davis et al., 1993).

The present study was undertaken to examine whether LIF receptor and gp130 are expressed in rabbit uterus during early pregnancy.

\section{Materials and Methods}

\section{Animals}

Mature New Zealand White-Cambridge crossbred female rabbits (Oryctolagus cuniculus) (body mass $>3.0 \mathrm{~kg}$; Penn Acres, Wimberley, TX) were caged individually in a controlled environment with a $14 \mathrm{~h}$ light: $10 \mathrm{~h}$ dark cycle. Oestrus was determined by the appearance of a dark reddish-purple mucosa in the vagina. Pregnant rabbits were obtained by injecting females s.c. with 0.5 iu porcine FSH (Sigma Chemical Co., St Louis, MO) twice a day for 3 days, and the females were naturally mated twice to fertile bucks, and then injected i.v. with 100 iu hCG (Sigma). All rabbits were killed by an i.v. injection of an overdose of pentobarbital sodium, and oviducts 
or uteri were removed, washed with PBS ( $\mathrm{pH} 7.4$ ) and flushed to recover embryos, which confirmed that the mated rabbits were pregnant. Pseudopregnancy was induced by treating females in the same way with FSH and hCG, but females were not mated. The uteri were removed and washed as above. Tissue sections were taken and treated as described below.

\section{Immunolocalization of $g p 130$}

Anti-human gp130 polyclonal antibody, prepared by immunizing guinea-pigs with the extracellular portion of recombinant soluble human gp130 expressed in Chinese hamster ovary (CHO) cells (Yasukawa et al., 1992), inhibits osteoclastic bone resorption induced by IL- 6 in rabbit cells (K. Yasukawa, unpublished). These experiments indicated that this polyclonal antibody crossreacts with rabbit gp 130 .

The uterine sections were fixed with $4 \%$ formaldehyde $(v / v)$ in PBS and stored overnight in $30 \%(\mathrm{w} / \mathrm{v})$ sucrose-PBS before use. Cryostat sections $(8 \mu \mathrm{m})$ were cut and fixed in cold acetone for $4 \mathrm{~min}$ at $-20^{\circ} \mathrm{C}$. Nonspecific binding was blocked by incubation with normal rabbit serum for $30 \mathrm{~min}$. The sections were then incubated with guinea-pig anti-recombinant human gp130 antibody (rhgp130; TOSOH Corp., Osaka) diluted with $0.1 \%$ BSA-Tris-buffered saline (TBS) $\left(0.01 \mathrm{~mol}\right.$ Tris- $\mathrm{HCl} \mathrm{l}^{-1}$, $\mathrm{pH} 7.4,0.9 \% \mathrm{NaCl}(\mathrm{w} / \mathrm{v}) ; \mathrm{I}: 600)$ for $1 \mathrm{~h}$ at $4^{\circ} \mathrm{C}$, and then with biotinylated goat anti-guinea-pig antiserum, a complex of avidin-biotinylated alkaline phosphatase and substrate kit for alkaline phosphatase (Vectastain, ABC-AP kit: Vector Laboratories, Burlingame, $C A$ ). Endogenous alkaline phosphatase was inhibited with levamisole (Vector Laboratories). After fixation in $4 \%$ formaldehyde-PBS for $20 \mathrm{~min}$, the sections were dehydrated and mounted. For control sections, guinea-pig antirhgp130 antibody was replaced by preimmune guinea-pig serum. An epifluorescence microscope with a rhodamine filter was used to visualize gp130.

\section{Localization of LIF receptor}

Recombinant mouse LIF (rmLIF; R\&D Systems, Minneapolis, MN) was biotinylated using a kit from Pierce (Rockford, IL). Labelling was carried out on ice for $2 \mathrm{~h}$. Unconjugated biotin was removed by dialysis with $2 \times 2 \mathrm{l}$ of TBS at $4^{\circ} \mathrm{C}$ overnight. The labelled rmLIF was stored at $4^{\circ} \mathrm{C}$ with the addition of $0.02 \%(\mathrm{w} / \mathrm{v})$ sodium azide. The cryostat sections of the uteri were digested with $0.1 \%(\mathrm{w} / \mathrm{v})$ trypsin and $0.1 \%(\mathrm{w} / \mathrm{v}) \mathrm{CaCl}_{2}$ in TBS for $30 \mathrm{~min}$. Nonspecific binding was blocked by incubation with normal horse serum (Vector Laboratories) for $30 \mathrm{~min}$. The sections were then incubated with biotinylated rmLIF (1.05 ng $\mathrm{I}^{-1}$ : total volume $70 \mu \mathrm{l}$ ) at $4^{\circ} \mathrm{C}$ overnight. After complete rinsing with $0.1 \%(\mathrm{w} / \mathrm{v}) \mathrm{BSA}-\mathrm{TBS}$, a complex of avidin and biotinylated alkaline phosphatase and substrate was applied (Vector Laboratories). Endogenous alkaline phosphatase was inhibited by levamisole. After fixation in $4 \%(\mathrm{v} / \mathrm{v})$ formaldehyde-PBS for $20 \mathrm{~min}$, the sections were dehydrated and mounted. For a control, TBS was used to replace the biotinylated rmLIF. For competition, sections of uterus of a rabbit at day 5 after blocking with normal horse serum, were then incubated with a 50-times excess of unlabelled rmLIF for $30 \mathrm{~min}$ at room temperature. The biotinylated rmLIF (the same concentration as used for normal binding) was then added, reducing the concentration of unlabelled rmLIF to a 25-times excess, and the sections were incubated at $4^{\circ} \mathrm{C}$ overnight.

\section{Results}

sp130

The wall of the rabbit uterus comprises layers of serosa, myometrium and endometrium. The myometrium is composed of bundles of smooth muscle fibres separated by connective tissue, whereas the endometrium consists of luminal epithelium, tubular glands and stroma.

The stromal cells did not show gp130 staining in unmated rabbits and in mated rabbits up to day 7 of pregnancy. In addition, gp130 was not detected in endometrial glands during the same stages, even though these glands were highly developed just before implantation.

However, the appearance of gp130 in the endometrial epithelium changed during early pregnancy. Little gp130 was present in the epithelium in non-oestrous and oestrous unmated rabbits, and none was present in the control section (Fig. 1a-c). Expression of gp130 increased on day 1 of pregnancy and maintained the same expression up to day 5 of pregnancy (Fig. $1 \mathrm{~d}-\mathrm{h}$ ). On day 6 of pregnancy, its expression was higher, and a similar expression was found in the endometrial epithelium on day 6 of pseudopregnancy (Fig. Ii, j). On day 7 of pregnancy, when the blastocysts attached to the epithelium, gp 130 expression was slightly lower than that seen on day 6 of pregnancy, and expression on the mesometrial epithelium was higher than that on the antimesometrial epithelium. Expression at the implantation site was similar to that at nonimplantation areas (Fig. $1 \mathrm{k}-\mathrm{m}$ ). A summary of these changes is shown in Table 1.

Low concentrations of gp130 were detected on the myometria of nonpregnant, day 7 pregnant or day 6 pseudopregnant rabbits, but no expression was seen from day 1 to day 6 of pregnancy (Fig. In, o).

\section{LIF receptor}

Nonspecific binding of LIF to its receptors was blocked by the incubation with normal horse serum. When TBS was used to replace the biotinylated rmLIF, no staining was found in the uterus on day 5 of pregnancy (Fig. 2a). This showed the specificity of the binding of LIF to its receptor. This was verified further by preincubating the sections for competition with a 50 -times excess of unlabelled rmLIF, followed by the same incubation as the sections for binding, but still in the presence of a 25-times excess of unlabelled rmLIF. The competition significantly inhibited the binding compared with that seen in the day 5 pregnant uterus (Fig. $2 \mathrm{~h}, \mathrm{i}, \mathrm{p}, \mathrm{q}$ ).

No LIF binding was detected on stromal cells of uteri from unmated, pseudopregnant or pregnant rabbits from days I to 7 . LIF binding on luminal and glandular epithelium was similar, and the pattern of binding was similar to that observed on myometrium. Little binding was seen in the epithelium of nonoestrous rabbits, but a moderate level of binding was seen in oestrous rabbits and on day 1 of pregnancy, which declined 

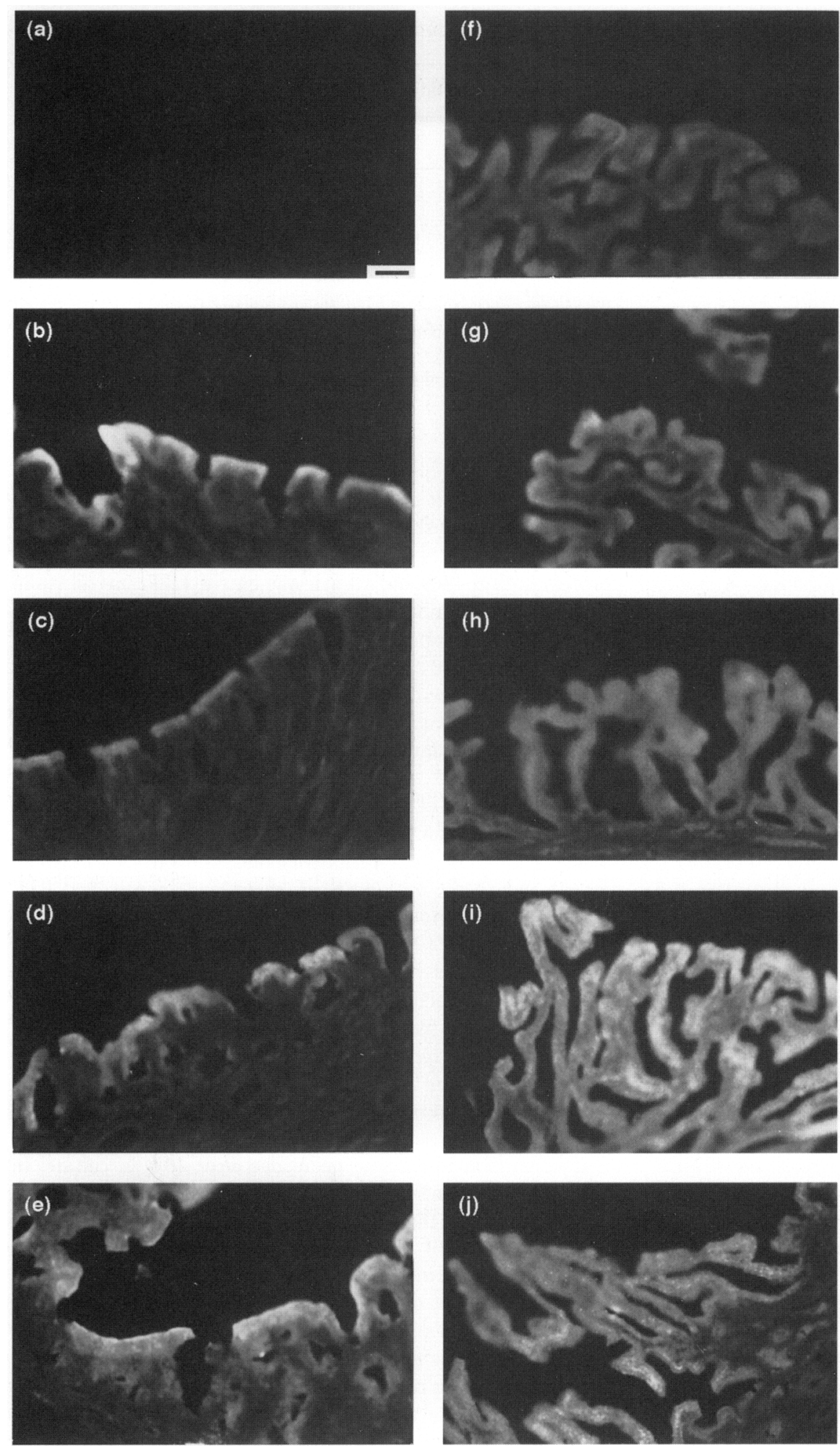
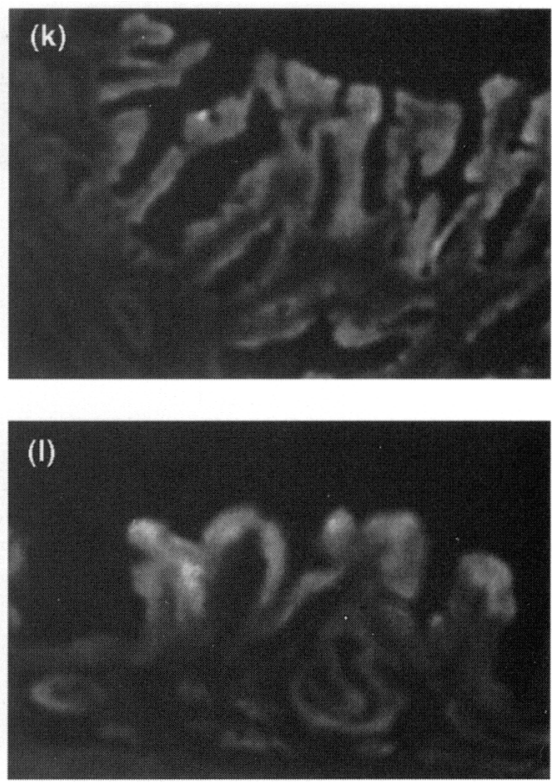

(m)
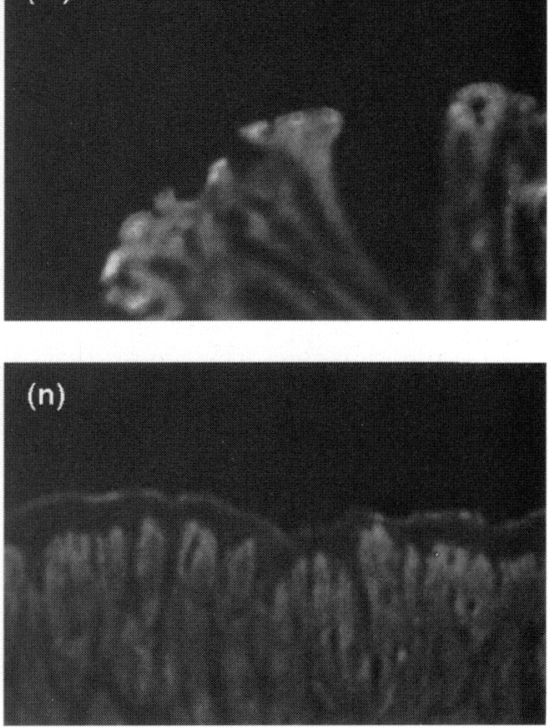

(o)

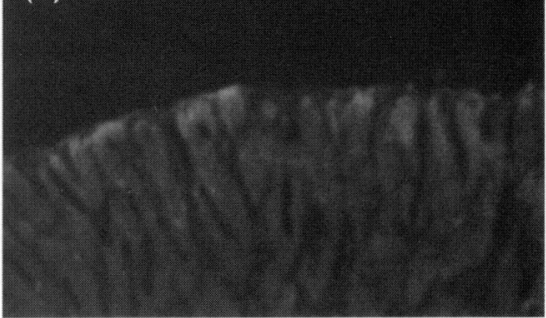

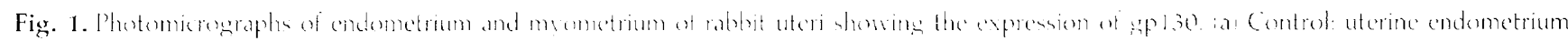

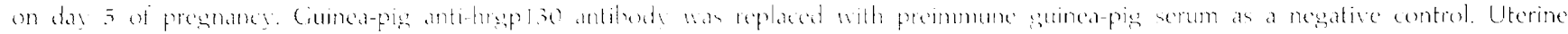

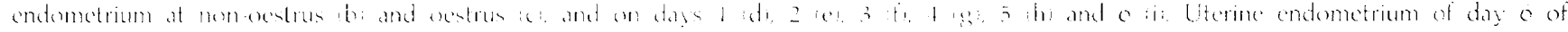

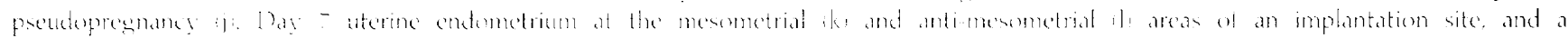

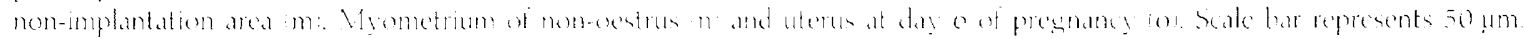


Table 1. Pattern of expression of gp130 in the rabbit uterus

\begin{tabular}{|c|c|c|c|c|c|c|c|c|c|c|c|}
\hline \multirow{2}{*}{$\begin{array}{l}\text { Site in } \\
\text { uterus }\end{array}$} & \multirow{2}{*}{$\begin{array}{c}\text { Non- } \\
\text { oestrus }\end{array}$} & \multirow[b]{2}{*}{ Oestrus } & \multicolumn{9}{|c|}{ Days after mating } \\
\hline & & & 1 & 2 & 3 & 4 & 5 & 6 & PS6 & $7(\mathrm{NI})$ & $7(\mathrm{I})$ \\
\hline EP & + & $+1-$ & $+t$ & ++ & + & ++ & ++ & +++ & +++ & ++ & ++ \\
\hline EG & $+1-$ & - & $+1-$ & - & - & - & - & $+1-$ & - & - & - \\
\hline ST & - & - & - & - & - & - & - & - & - & - & - \\
\hline Myo & + & $+1-$ & - & - & - & - & - & - & + & ++ & + \\
\hline
\end{tabular}

EP: luminal epithelium; EG: endometrial glands; ST: stroma; Myo: myometrium; PS: pseudopregnancy; I: implantation area; NI: non-implantation area.

- : Negative; $+/-$ : minimally positive; + : positive; ++ : moderately positive; +++ : strongly positive.

on day 2 of pregnancy (Fig. $2 \mathrm{~b}-\mathrm{e}$ ). LIF binding then increased from day 3 of pregnancy, and was highest on days 5 and 6 of pregnancy (Fig. $2 \mathrm{f}-\mathrm{h}, \mathrm{j}$ ). A high level of LIF binding was also found on day 6 of pseudopregnancy (Fig. 2k). The binding on day 7 of pregnancy was lower than that seen on days 5 and 6 , except for that in the antimesometrial area, where it was similar (Fig. $21-n$ ). Little binding was seen on day 7 in the nonimplantation areas (Fig. 20). A summary of these changes is shown in Table 2.

LIF binding was detected on the myometrium. The binding was moderate at oestrus, at nonoestrus (Fig. 2q) and on day 1 of pregnancy, but declined on days 2 and 3 of pregnancy. LIF binding began to increase again on day 4 of pregnancy, reaching its highest level on days 5 and 6 of pregnancy (Fig. $2 \mathrm{p}-\mathrm{r}$ ). A high level of LIF binding was also observed on day 6 of pseudopregnancy. The binding to the myometrium on the mesometrial side of the implantation site and of nonimplantation areas was lower than that seen on days 5 and 6 of pregnancy (Fig. $2 \mathrm{~m}, \mathrm{n}$ ).

\section{Discussion}

These results show that both gp130 and LIFR were present in the rabbit uterus during early pregnancy. Expression of gp 130 was greatest in the epithelium on day 6 of pregnancy, the day before implantation. No expression was detected on stromal cells or on endometrial glandular epithelium. Expression on the myometrium was at basal values. Unlike the expression of gp130, LIF binding during early pregnancy changed on the myometrium and glandular epithelium, and the highest LIF binding was found on days 5 and 6 of pregnancy. No binding was found on stromal cells.

The binding of LIF on luminal epithelium showed a similar pattern to that of gp130: the highest binding was observed on days 5 and 6 of pregnancy. The pattern of LIF binding to all uterine structures was similar to the pattern of expression of LIF protein in the pregnant rabbit uterus (Yang et al., 1994), but, in contrast, only expression of gp130 on the luminal epithelium was similar to that of LIF protein (Yang et al., 1994). In mice, the highest expression of mRNA encoding LIF (using RNase protection) is found in the endometrial glands on day 4 of pregnancy, just before implantation on day 5; weaker signals were observed in the epithelium lining the uterine lumen on days 2, 3 and 5, and a slightly increased signal on day I (Bhatt et al., 1991). In general, expression of mRNA encoding LIF in the mouse uterus is greater in the glandular than in the luminal epithelium at all stages studied. No data are available on expression of mRNA encoding LIF in rabbit uterus, but LIF protein and gp130, and to a lesser extent LIFR, are all more strongly evident in luminal than in glandular epithelium in this species (present paper and Yang et al., 1994).

The expression of gp130 and LIFR in the uteri of other species has not been studied. Since the temporal pattern of LIF expression in the rabbit uterus was similar to that in mice, it is possible that the same applies for LIFR and gp130 expression in the mouse uterus.

A comparison of the five LIF protein sequences available (mouse, rat, human, sheep and pig) reveals that the protein displays a high degree of similarity ranging from $74 \%$ between mouse and sheep, $88 \%$ between sheep and human, and $92 \%$ between rat and mouse (Stahl et al., 1990; Willson et al., 1992). Owczarek et al. (1993) showed that a series of 15 mousehuman LIF hybrid proteins retain full biological activity and receptor-binding activity in mouse cells, and that there is little variation in the specific biological activity of the purified proteins. Primary binding sites of mLIF and hLIF to the mLIFR may therefore be unaltered by the interspecies domain exchange. The addition of $1000 \mathrm{U}_{\text {rhLIF } \mathrm{ml}^{-1}}$ to culture media increases by fourfold the number of sheep embryos at day 5 that hatch from the zonae pellucidae after $48 \mathrm{~h}$ in culture. In addition, fewer embryos degenerate when cultured in media containing rhLIF (Fry et al, 1992). Rabbit LIF protein and antibody for rabbit LIFR are not commercially available. The high degree of homogeneity between interspecies LIF protein permitted the use of the biotinylated rmLIF to demonstrate LIFR in the rabbit uterus.

Several authors identify gp130 as a component of the functional receptor complexes of LIF, oncostatin M, IL-6, ciliary neurotrophic factor and IL-11 (Rose and Bruce, 1991; Gearing et al., 1992; Davis et al., 1993; Neben and Turner, 1993). All of the receptors can interact with the signal transducing receptor gp130 after ligand binding (Neben and Turner, 1993). Although gp130 does not bind to either LIF or IL-6, the complex of gp130 with the low affinity $\beta$ subunit of LIFR confers high affinity to the LIFR and transduces the signal to activate the Jak-Tyk family of cytoplasmic tyrosine kinases, as does the IL-6R $\alpha$ and gp130-homodimer complex (Davis $e$ t al., 1993; Murakami et al., 1993; Lütticken et al., 1994; Stahl et al., 

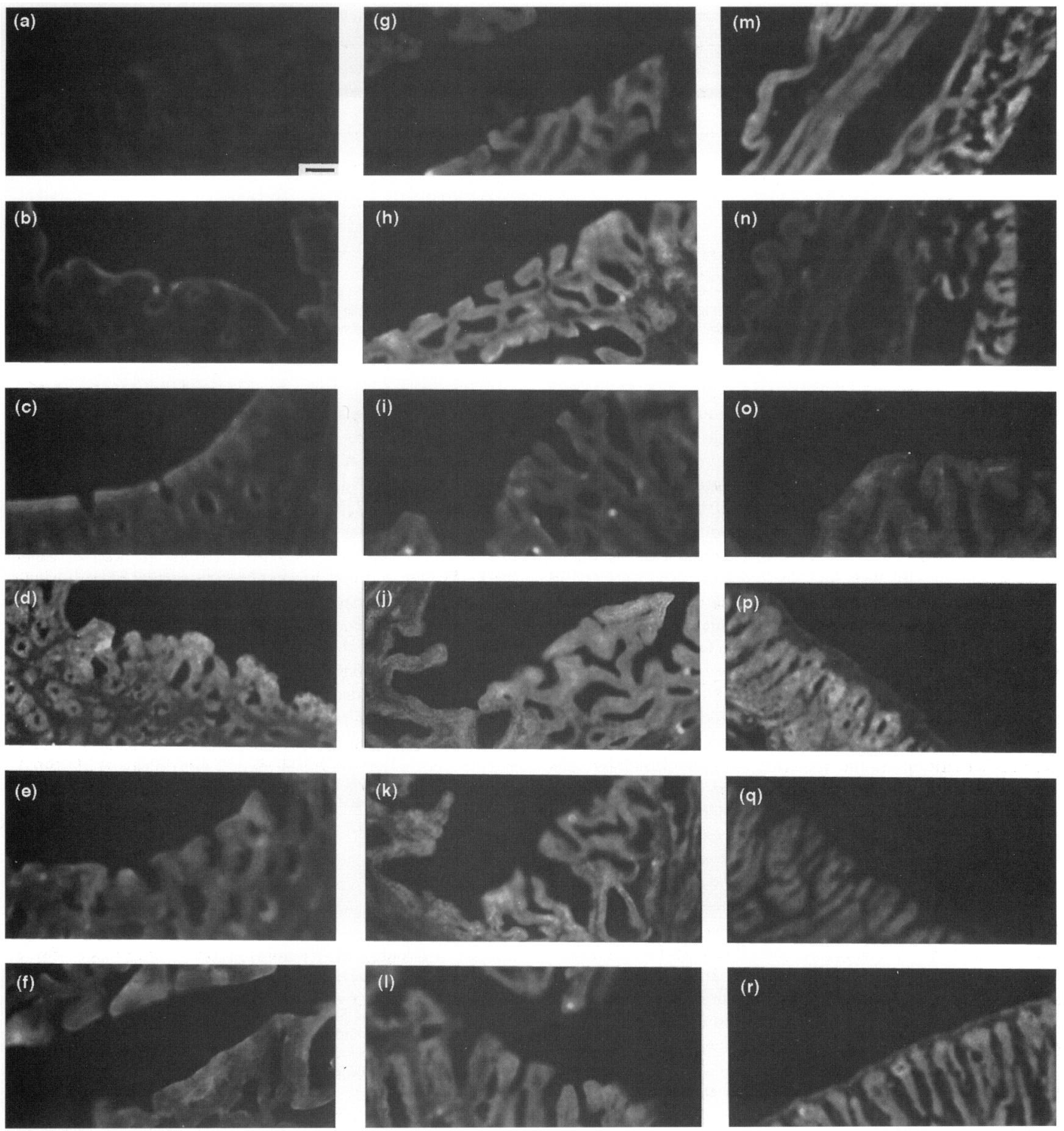

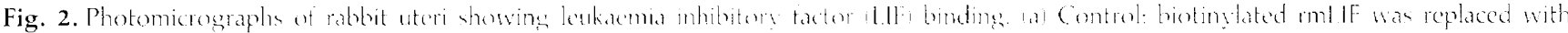

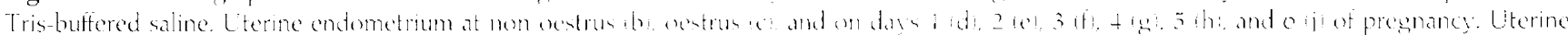

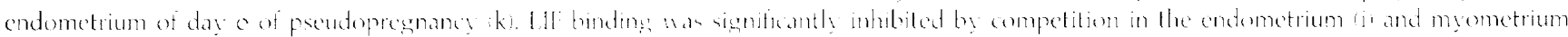

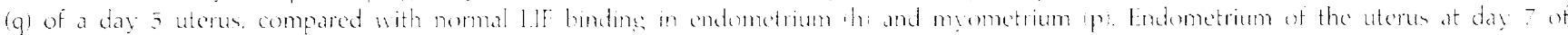

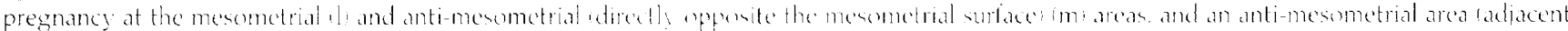

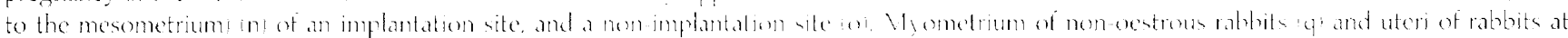

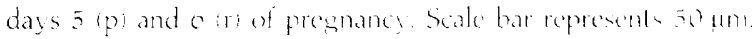

1994). Oncostatin $M$ is a single cytokine identified a a mitural ligand for gp 130, a low attinity receptor form, whith meethates the biologicat respemses of oncostatin . W. However. oncowat in
$M$ an also bind with high affirity to the LIFRB-gp 130 complex but LIF competes with such binding Coearing and Bruce, 1002: Goaring it al, 1002, Liu it al, 1002!. Thus, 
Table 2. Pattern of LIF binding in the rabbit uterus

\begin{tabular}{|c|c|c|c|c|c|c|c|c|c|c|c|c|c|}
\hline \multirow{2}{*}{$\begin{array}{l}\text { Site in } \\
\text { uterus }\end{array}$} & \multirow[b]{2}{*}{$\mathrm{NE}$} & \multirow[b]{2}{*}{$\mathrm{E}$} & \multicolumn{11}{|c|}{ Days after mating } \\
\hline & & & 1 & 2 & 3 & 4 & 5 & $5^{*}$ & 6 & PS6 & $7(\mathrm{NI})$ & $7(\mathrm{MI})$ & $7(\mathrm{AMI})$ \\
\hline $\mathrm{EP}$ & + & ++ & ++ & + & ++ & ++ & +++ & + & $+t+$ & +++ & ++ & ++ & ++ \\
\hline $\mathrm{EG}$ & + & + & + & $+1-$ & + & + & $++t$ & + & +++ & +++ & ++ & ++ & ++ \\
\hline ST & - & - & - & - & - & - & - & - & - & - & - & - & - \\
\hline Myo & ++ & +++ & ++ & + & $+1-$ & $+t$ & +++ & + & +++ & +++ & ++ & ++ & +++ \\
\hline
\end{tabular}

*For competition.

NE: non-oestrus; E: oestrus; ST: stroma; EP: luminal epithelium; EG: endometrial glands; Myo: myometrium; PS: pseudopregnancy; NI: non-implantation area; MI: mesometrium at an implantation area; AMI: anti-mesometrium at an implantation area.

- : Negative; $+I-$ : minimally positive; + : positive; ++ : moderately positive; +++ : strongly positive.

oncostatin M binding to LIFR is unlikely to affect the observed pattern of LIF binding. The size of LIFR has been measured by affinity cross-linking and is found to be approximately $250 \mathrm{kDa}$ (Godard et al., 1992). IL-6 binds to its receptor IL-6R $\alpha$, and then to a gp130 homodimer to induce signal transduction. Thus, localization of gp130 by a specific antibody can indicate the presence of oncostatin M, LIF, ciliary neurotrophic factor or IL-6 receptors. Because of the presence of the $\mathrm{gp} 130$ homodimer in the high-affinity form of the IL-6R (Davis $e$ t al., 1993), the brightest signal not colocalized with LIFR is probably due to the presence of IL-6R; weaker signals may indicate the presence of oncostatin $\mathrm{M}$ or ciliary neurotrophic factor receptors.

The cloned human LIFR encodes a $200 \mathrm{kDa}$ glycoprotein that specifically binds human, but not mouse, LIF with low affinity (1-2 nmol I ${ }^{-1}$; Gearing et al., 1991). Because most cells responding to LIF express both low- and high-affinity receptors, a functional LIFR complex may require the coexpression of the high-affinity conversion component, gp130, and the low-affinity LIFR $\beta$ receptor (Gearing et al., 1991; Gearing, 1993). Since gp130 does not bind LIF, the receptors identified with biotinylated rmLIF in our studies should be either low-affinity or high-affinity receptors. Furthermore, the required coexpression of gpI30 and LIFR $\beta$ subunit may imply that the coexistence of gp130 and LIFR in rabbit endometrial epithelium may denote the site of high-affinity LIFR. Since only LIF binding was seen on myometrium and endometrial glands, where gP130 was not expressed, the LIFR at these sites may be the low-affinity receptors.

The high concentration of functional high-affinity LIFR and of LIF on the luminal epithelium just before implantation may be essential for implantation in rabbits, as is the case in mice (Stewart ef al., 1992). Moreover, as LIF is a pleiotropic cytokine and the gp130 receptor component is shared by several other cytokines, co-existence of LIFR and LIF protein may be important for the localized action of LIF. An immobilized, matrix-targeted form of the LIF ligand (Rathjen et al, 1990) and an extracellular matrix-associated LIFR (Mereau et al., 1993) have been identified, suggesting that extracellular localization of LIF and LIF signal transduction may be closely coupled. A soluble form of LIFR was identified in mouse serum that may have the ability to block unwanted systemic actions of locally produced LIF (Layton et al., 1992).
The fact that the amount and site of expression of LIF and LIFR are similar in pregnant and pseudopregnant rabbits confirms the observations in the mouse that it is maternal, and not embryonic, LIF that is critical for blastocyst implantation (Stewart et al., 1992; Yang et al., 1994; this paper). Furthermore, it was reported that expression of mRNA encoding LIF is higher in secretory than in proliferative phase human endometrium, and that this expression is three times higher in an epithelial-compared with a stromal-enriched cell fraction, suggesting that LIF is also important for human implantation (Kojima et al., 1994). What has yet to be resolved is which components of the implantation process - angiogenesis, attachment, invasion or decidualization - are regulated by LIF binding, activation of tyrosine kinase and tyrosine phosphorylation.

The authors thank B. S. Dunbar, Department of Cell Biology, for her helpful suggestions regarding the LIF binding study. These studies were supported by NIH grants HD 14048 and HD 07495 (Center for Reproductive Biology Research: Principal Investigator Dr B. W. O'Malley).

\section{References}

Baumann H and Wong GG (1989) Hepatocyte-stimulating factor III shared structural and functional identity with leukemia inhibitory factor Journal of Immunology 143 1163-1167

Bhatt H, Brunet LJ and Stewart CA (1991) Uterine expression of leukemia inhibitory factor coincides with the onset of blastocyst implantation Proceedings of the National Academy of Sciences USA 8811 408-11 412

Davis S, Aldrich TH, Stahl N, Pan L, Taga T, Kishimoto T, Ip NY and Yancopoulos GD (1993) LIFR $\beta$ and gp130 as heterodimerizing signal transducers of the tripartite CNTF receptor Science 260 1805-1808

Fry RC, Batt PA, Fairclough RJ and Parr RA (1992) Human leukemia inhibitory factor improves the viability of cultured ovine embryos Biology of Reproduction 46 470-474

Gearing DP (1993) The leukemia inhibitory factor and its receptor Advances in Immunology 53 31-58

Gearing DP and Bruce AG (1992) Oncostatin M binds the high-affinity leukemia inhibitory factor receptor New Biology 4 61-65

Gearing DP, Thut CJ, VandenBos T, Gimpel SD, Delaney PB, King J, Price V, Cosman D and Beckmann MP (1991) Leukemia inhibitory factor is structurally related to the IL-6 signal transducer, gp130 EMBO Journal 10 2839-2848

Gearing DP, Comeau MR, Friend DJ, Gimpel SD, Thut CJ, McGourty J, Brasher KK, King JA, Gillis S, Mosley B, Ziegler SF and Cosman D (1992) The IL-6 signal transducer, $\mathrm{gp} 130$ : an oncostatin $\mathrm{M}$ receptor and affinity converter for the LIF receptor Science 255 1434-1437 
Godard A, Heymann D, Raher S, Agegon I, Peyrat MA, Le Mauff B, Mouray E, Gregoire M, Virdee K, Soulilloi JP, Moreau JF and Jacques Y (1992) High and low affinity receptors for human interleukin for DA cells/leukemia inhibitory factor on human cells Journal of Biological Chemistry $2673214-3222$

Hilton DJ, Nicola NA and Metcalf D (1988) Specific binding of murine leukemia inhibitory factor to normal and leukemic monocytic cells Proceedings of the National Academy of Sciences USA 85 5971-5975

Hilton DJ, Nicola NA and Metcalf D (1991) Distribution and comparison of receptor for leukemia inhibitory factor on murine hemopoietic and hepatic cells Journal of Cell Physiology 146 207-215

Kojima K, Kanzaki H, Iwai M, Hatayama H, Fujimoto M, Inoue T, Horie K, Nakayama H, Fujita J and Mori T (1994) Expression of leukemia inhibitory factor in human endometrium and placenta Biology of Reproduction 50 882-887

Layton MJ, Cross BA, Metcalf D, Ward LD, Simpson RJ and Nicola NA (1992) A major binding protein for leukemia inhibitory factor in normal mouse serum: identification as a soluble form of the cellular receptor Proceedings of the National Academy of Sciences USA 89 8616-8620

Liu \}, Modrell B, Aruffo A, Marken JS, Taga T, Yasukawa K, Murakami M, Kishimoto $T$ and Shoyab M (1992) Interleukin-6 signal transducer gp130 mediates oncostatin $M$ signaling Journal of Biological Chemistry 267 16763-16766

Lütticken C, Wegenka UM, Yuan J, Buschmann J, Schindler C, Ziemiecki A, Harpur AG, Wilks AF, Yasukawa K, Taga T, Kishimoto T, Barbieri G, Pellegrini S, Sendtner M, Heinrich PC and Horn F (1994) Association of transcription factor APRF and protein kinase Jak 1 with the interleukin- 6 signal transducer gp130 Science 263 89-92

Matsui Y, Zsebo K and Hogan BLM (1992) Derivation of pluripotential embryonic stem cells from murine primordial germ cells in culture Cell 70 841-847

Mereau A, Grey L, Piquet-Pellorce C and Heath JK (1993) Characterization of a binding protein for leukemia inhibitory factor localized in extracellular matrix Journal of Cell Biology 122 713-719

Moreau JF, Donaldson DD, Bennett F, Witek GJ, Clark SC and Wong GG (1988) Leukemia inhibitory factor is identical to the myeloid growth factor human interleukin for DA cells Nature 336 690-692

Mori M, Yamaguchi K and Aba K (1989) Purification of a lipoprotein lipase inhibiting protein produced by melanoma cell line associated with cancer cachexia Biochemical Biophysical Research Communication 160 1085-1092

Murakami M, Hibi M, Nakagawa N, Nagakawa T, Yasukawa K, Yamanishi K, Taga $\mathrm{T}$ and Kishimoto $\mathrm{T}$ (1993) IL-6-induced homodimerization of gp130 and associated activation of a tyrosine kinase Science 260 1808-1810

Murray R, Lee F and Chiu C.P (1990) The genes for leukemia inhibitory factor and interleukin- 6 are expressed in mouse blastocysts prior to the onset of hemopoiesis Molecular and Cellular Biology 10 4953-4956
Neben S and Turner K (1993) The biology of interleukin 11 Stem Cells 11 (Supplement 2) 156-162

Owczarek CM, Layton MJ, Metcalf D, Lock P, Willson TA, Gough NM and Nicola NA (1993) Inter-species chimeras of leukemia inhibitory factor define a major human receptor-binding determinant EMBO Journal 12 3487-3495

Rathjen PD, Toth S, Willis A, Heath JK and Smith AG (1990) Differentiation inhibiting activity is produced in matrix-associated and diffusible forms that are generated by alternate promoter usage Cell 62 1105-1114

Rose TM and Bruce AG (1991) Oncostatin M is a member of a cytokine family that includes leukemia-inhibitory factor, granulocyte colony-stimulating factor and interleukin 6 Proceedings of the National Academy of Sciences, USA 88 8641-8645

Smith AG, Heath JK, Donaldson DD, Wong GG, Moreau J, Stahl M and Rogers D (1988) Inhibition of pluripotential embryonic stem cell differentiation by purified polypeptides Nature 336 688-690

Stahl J, Gearing DP, Willson TA, Brown MA, King JA and Gough NM (1990) Structural organization of the genes for murine and human leukemia inhibitory factor: evolutionary conservation of coding and noncoding regions Journal of Biological Chemistry 265 8833-8841

Stahl N, Boulton TG, Farruggella T, Ip NY, Davis S, Witthun BA, Quelle FW, Sivennoinen O, Barbieri G, Pellegrini S, Ihle JN and Yancopoulos GD (1994) Association and activation of Jak-Tyk kinases by CNTF-LIF-OSM-IL-6 $\beta$ receptor components Science 263 91-95

Stewart CC, Kaspar P, Brunet LJ, Bhatt H, Gadi I, Köntgen F and Abbondanzo SJ (1992) Blastocyst implantation depends on maternal expression of leukemia inhibitory factor Nature 359 76-79

Willson TA, Metcalf D and Gough NM (1992) Cross-species comparison of the sequence of the leukemia inhibitory factor gene and its protein European Journal of Biochemistry 204 21-30

Yamamori T, Fukada K, Aebersold R, Korshing S, Fann MJ and Patterson PH (1989) The cholinergic neuronal differentiation factor from heart cells is identical to leukemia inhibitory factor Science 246 1412-1416

Yamamoto-Yamaguchi Y, Tomida M and Hozumi M (1986) Specific binding of a factor inducing differentiation to mouse myeloid leukemic M1 cells Experimental Cell Research 164 97-102

Yang Z-M, Le S-P, Chen D-B and Harper MJK (1994) Temporal and spatial expression of leukemia inhibitory factor in rabbit uterus during early pregnancy Molecular Reproduction and Development 38 148-152

Yasukawa K, Futatsugi K, Saito T, Yawata H, Narazaki M, Suzuki H, Taga T and Kishimoto T (1992) Association of recombinant soluble IL-6-signal transducer, gp130, with a complex of IL-6 receptor, and establishment of an ELISA for soluble gp130 Immunology Letters 31 123-130 